\title{
How Twentieth Century Greek Scholars Influenced the Works of Nineteenth Century Greek Translators of 'The Poems of Ossian' by James Macpherson
}

\author{
By Kathleen Ann O’Donnell*
}

Did the influence towards Nineteenth Century translators of The Poems of Ossian by the Scot, James Macpherson result in any neglect in the following century? In this article, I discuss the only paper that deals with the subject of Ossian at length, entitled 'Ossian in Greece' by the scholar Nassos Vagenas, which was published in the periodical Parnassos in April, 1967, when the military junta came into power. Various comments will be made on Vagenas's paper among which will be the 1850 translation of 'Calmar and Orla' as well as the Twentieth Century translation by Stathis Spiliotopoulos, entitled 'Ossian Poems' into poetry in book form in demotic Greek, the official language in 1936 under General Metaxa, the Modern Greek dictator. It was published three months before the public burning of books: the works of Goethe were on the pyre. The 1994 award winning 'The Sorrows of Young Werther' by Goethe, which include 'The Songs of Selma' and a short extract from 'Berrathon', translated by Stella G. Nikoloudi, will also be mentioned together with the biography entitled 'Panayiotis Panas: A Romantic Radical' by the scholar Erasmia Louisa Stavropoulou, published in 1987. Panayotis Panas was the main Nineteenth Century translator of this Celtic poetry. This Scottish work was translated by Nineteenth Century translators from English, Italian and French into Modern Greek Purist, the official language, and demotic poetry and prose. Reference to the enrichment of the language from the neologisms and recycled ancient Greek words in translations of this Celtic work, which are included in the 1991 dictionary compiled by Tegopoulos and Phytrakis, will reveal if true recognition was given to the Nineteenth Century translators.

The aim of this paper is to demonstrate how Twentieth Century Modern Greek literary critics influenced the work of Nineteenth Century Modern Greek translators of 'The Poems of Ossian' by the Scot, James Macpherson. Were these literary critics neglectful in their assessment of the penetration of the impact that this poetry had on Modern Greek culture?

${ }^{*}$ Independent Scholar, British School at Athens, Greece.

https://doi.org/10.30958/ajp.1-4-4

doi=10.30958/ajp.1-4-4 
In the first part of this paper I shall point out inaccuracies and the consequences thereof, which are contained in the paper 'Ossian in Greece' written by the scholar and poet Nassos Vagenas (1967). Published in Athens in the Twentieth Century, 'Ossian in Greece' is the only paper that examines this subject at length. Then I shall discuss omissions, followed by their effect on Twentieth Century Modern Greek literature in the second part of my paper.

The article 'Ossian in Greece' was published in April 1967, at the start of a seven year rule by the Military Junta. Even though Greece was liberated in 1828, it excluded The Seven Islands, Crete, Thessaly, Epirus, Thrace, Macedonia and the Dodecanese Islands. While two of these provinces became part of Greece in the second part of the Nineteenth Century, the rest of the zone only united to Greece in the Twentieth Century, the last province being that of the Dodecanese Islands in 1947 (Stavrianos, 2000). Therefore the title 'Ossian in Greece' is inaccurate. This is substantiated by Vagenas who cites two full translations of 'Dar-thula' and 'Lathmon' published in the British Protectorate of the Seven Islands (1862) and an extract entitled 'The Dream of Cathmor and Sulmalla' from 'Temora IV', an epic, printed in Alexandria, in the Ottoman Empire (1863). All three poems, translated into Greek from Italian, were published by the Kephalonian scholar and journalist, Panayiotis Panas outside Greece.

In the 1862 translation of 'Dar-thula-Lathmon', translated into demotic poetry, Vagenas states that Dar-thula committed suicide on top of her lover (Vagenas, 1967). Panas omits any mention about Macpherson's statement regarding Dar-thula's suicide because Macpherson continues to explain that Ossian recounts the way Dar-thula died in a different way from the traditional story (Stafford, 1991, p.57). Macpherson also adds that no reference to suicide appears in this ancient poetry. Dar-thula was shot by arrows fired by the tyrant Cairbar.

'Oh! An arrow cruelly entered her bosom' (Panas, 1862)

'for an arrow was fixed in her side' (Gaskill, 1996, The poems of Ossian)

In this way Vagenas distorts the myth ${ }^{1}$. Panas chose this poem to reveal not only the sacrifice of three Nineteenth Century Greek patriots but also to expose the even more vicious tyranny of Cairbar and his 'komma' [political party] in his killing Dar-thula - a woman. Vagenas also fails to mention why Panas selected 'Dar-thula'. In introducing 'Dar-thula-Lathmon', in her biography of Panas, the scholar E. L. Stavropoulou states that Panas dedicated them to:

'the sacred memory of the vile and craven murder of the Heroes, Leotsakos, Moraitinis and Skarvelis'

(Stavropoulou, 1987).

\footnotetext{
${ }^{1}$ My copyrighted translation of 'Ossian in Greece' 1996 into English can be found at independent.academia.edu/KathleenAnnODonnell This translation must not be confused with an edited edition by Howard Gaskill of my translation, which omits this statement at JISCMail Highland Archives. https://www.jiscmail.ac.uk/cgi-bin/webadmin?INDEX=\&p=38 (A2=HIGHLANDS)
} 
In his preface, Panas compares these three Greek patriots, slaughtered in the Cycladic revolution in 1862, to Celtic heroes (Panas, 1862; O'Donnell, 2014).

When examining the third poem - an extract from 'Temora' Book IV included in Panas's book of poetry entitled 'Memnon', with an epigraph by Byron, Vagenas states that Panas astonishes us because he translates into Purist even though he was a fanatical demotic writer and a follower of Solomos, the national poet of Greece. Without ever stepping on Greek soil, Solomos, (17981856) became the National Poet of Greece when the British Protectorate handed over the Seven Islands to Greece in 1864. Solomos, whose works were published posthumously, only wrote in demotic Greek as most of his poetry was sung by illiterate natives, while the aristocracy spoke Italian, the official language of the Seven Islands under English rule. In a similar vein, Vagenas also refers to other translators of 'The Poems of Ossian' including the Athenian, Achilles Paraschos, who translated into demotic, then returned to his 'beloved' Purist. Vagenas continues to explain that Mavroyiannis, who although he recognised the demotic character of this poetry, translated it into Purist (Vagenas, 1967). During the Junta period, the official language was changed to Purist, which explains why it was accentuated. However, the language question did not really surface in Greece until 1880. Therefore, it seems more relevant to discuss content rather than whether poets used Purist or demotic as a means of translation, before 1880, as it was not a political issue. In Nineteenth Century Modern Greece, everything in prose and poetry was published in Purist so intellectuals wrote in that language although demotic poetry was accepted (Mackridge, 1992). It is noteworthy that Cesarotti used a simple form of Italian for the shorter poems while he chose a loftier style when translating the two epics of 'Fingal' and 'Temora', which explains why certain Greek translators used Purist when translating the epics 'Fingal' and 'Temora' (Gaskill, 1994). The subject that Vagenas is discussing is Ossian, yet a great deal of time is spent on the subject of language, which again is misleading.

Vagenas (1967) wrongly dates Panas's Alexandria translation as being 1863 when in fact it was dated 1865 (Panas, 1865). This leads one to believe $\tau$ hat 'The Poems of Ossian' were connected with and were used to support the union of the Seven Islands together with the crowning of yet another foreign monarch to Greece in 1864. In fact, 'Memnon' was published in Egypt just before a coup d'état 1865-6 (Guida, 2007). In 1996, I was kindly given a copy of this poem by Professor E. L. Stavropoulou, which is clearly stamped with 'The Library of K. T. Dimaras' a literary critic. Vagenas thanks Dimaras for his valuable information on Ossian at the beginning of his paper, in a footnote (Vagenas, 1967). This translation is not included in Dimaras's 'The History of Modern Greek Literature'. Dimaras states that the most influential translator of 'The Poems of Ossian' is the Italian translator M. Cesarotti. Yet, Cesarotti's name is omitted in the index of this book. The source of Panas's translation is also excluded, even though Panas clearly cites he has used Cesarotti's work (Dimaras, 1987). In Dimaras's book 'Greek Romanticism', which is also a handbook for Greek scholars in other fields of study who require an insight 
into Nineteenth Century Modern Greek literature, while foreign writers are indexed in Latin script, Cesarotti's name is in Modern Greek script, written

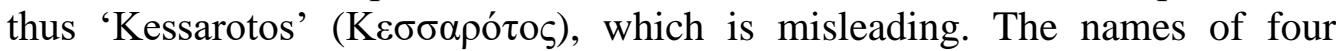
Nineteenth Century translators of 'The Poems of Ossian' including Panas, are mentioned, although the titles of their poems are omitted. When referring to Voltairos who had cited both Panas and Mavroyiannis as being previous translators in his preface, Dimaras claims that he himself has no idea as to who Mavroyiannis is. Yet Dimaras, in this book (1994), in an endnote, includes a short summary of Nassos Vagenas's 'Ossian in Greece', in which the translations of Mavroyiannis are discussed. There is no mention of the translation of 'The Death of Calmar and Orla', by Byron, translated into Greek in 1850 .

In 1850, an adaptation from 'Fingal' Book I, entitled 'Ossian. The Death of Calmar and Orla' by Byron' was translated by I. Georgantopoulos. It was published in the periodical 'Evterpe' (Georgantopoulos, 1850, pp.127-129). As Georgantopoulos cites Byron's name as his source in his publication, the connection of Byron with Ossian was read by Greek-speaking people not only in Athens where it was published but in the Ottoman Empire, Dacia and the Seven Islands as well, where it was distributed. Byron saw worthiness in writing an adaptation from the epic 'Fingal' from 'The Poems of Ossian' despite the fact that he knew about the controversy, which he states clearly at the end of his adaptation. This led to inspire Georgantopoulos to translate his work, which influenced other Modern Greek scholars to translate Ossian. Byron also included epigraphs from 'Carthon' and 'Oina-morul' in his 'Newstead' poems. Byron was one of the most important philhellenes who gave his life in the fight for Greek independence. He translated the 'Battle Cry' by Rigas, the Greek hero (Byron, 1919). Before sacrificing his life in the Greek Revolution in Missolonghi in April 1824, Byron first resided in Kephalonia for several months. When Kephalonians were buried in a landslide, while working in a corvée, imposed by the British Protectorate, Byron immediately dismounted his horse and began digging in an attempt to rescue the buried workers (Ravanis, 1982). Undoubtedly the culmination of the above inspired Kephalonians to translate 'The Poems of Ossian'. Vagenas omits Byron's name stating that this translation went completely unnoticed because translators never mentioned the poet at all or the legend to which he, Ossian, owed much of his success. This gross negligence severed any connection that existed between Byron and Ossian in the Nineteenth Century and consequently, the Twentieth Century in Greece. This presents a false picture to students of English literature at Athens University, who were required to read 'Ossian in Greece' as part of the syllabus. Another omission by Vagenas was that of 'The Songs of Selma' which was included in 'The Sorrows of Young Werther' by Goethe.

Instead of communicating to the Greek reader that Goethe included 'The Songs of Selma' in 'The Sorrows of Young Werther', Vagenas informs us that Herder translated the famous 'The Songs of Selma' and thus made Ossian available to Goethe who was attracted to the bard's poetry immediately 
(Vagenas, 1967). When researching 'Fingal' by Voltairos, Vagenas would have read his long critical diatribe, which was drawn from works by Villemain, Blair, Macpherson and Cesarotti among others. Voltairos not only included a footnote in his discussion on 'The Songs of Selma' but also stated that Goethe had copied the whole of this poem into 'The Sorrows of Young Werther' as well (Voltairos, 1869) ${ }^{1}$. In fact, there were three translations into Modern Greek in the Nineteenth Century. In 1843, I. S. Semptellis translated 'The Sorrows of Young Werther' from French, possibly from Pierre Leroux's version (Denisis, 1995). Pierre Leroux was a French philosopher and economist. He was a socialist and main instigator of the 1848 French Revolution (Gsteiger, 1977, p.48) ${ }^{2}$. The 1843 publication of 'Werther' coincided with the first publication of the newspaper 'Rigas' by the Zakinthian scholar George Tertsetis in Athens, printed in the demotic language, in the same year (Bouboulidos, 1950). In 1848, N. I. Saltellis translated and published 'Werther' in Smyrna, without naming his source. In 1879, Panayiotis Pamboukis translated his version from German, in Athens (Denisis, 1995).

It can thus be ascertained that the beginning of the influx of Ossian into Greece began in 1843 with 'The Songs of Selma' included in 'Werther' by Goethe, in Athens and Smyrna in the Ottoman Empire in 1848 and Byron's adaptation of 1850. This fact is omitted by Vagenas who claimed that the Heptanesians introduced Ossian into Athens in 1862, almost twenty years later (Vagenas, 1967).

A recent translation of 'Werther' by Stella Nikoloudis, who was awarded a prize for her translation in 1994 (Goethe, 1996), makes no reference to either previous Nineteenth Century translators or to the 1963 translation into demotic Greek by Minas Zografou from the French version by Pierre Leroux (Goethe, 1963).

Vagenas states that Athenian Romantics welcomed Ossian with interest, which changed to admiration. But it was far too late. Greek romanticism approached its end and Ossian had nothing to offer it. Vagenas completes his research with a long footnote of thirty-four lines, which merely lists further translators in the Nineteenth Century thus trivialising their importance.

In three lines, Vagenas (1967) enumerates Andreas N. Kephallinos as being a Kephalonian when in fact he was a Corfiot scholar and translator of Sanscrit, who collaborated with the Corfiot political activist and translator of 'Hymn to the Sun' from 'Carthon', Stylianos Chrisomallis, in the very successful 1880-81 opera 'Oithona' (composed by the Corfiot Rothotheatos). Kephallinos translated 'Oithona' from English into Modern Greek demotic prose in 1880 (Kardamis, 2012; Kephallinos, 1880a). In this way Vagenas diverts any connection between the Corfiot scholars. Vagenas, who discusses the forms of Greek languages used in translations of Ossian, fails to mention

\footnotetext{
${ }^{1}$ In the edited edition of my translation by Howard Gaskill it is stated that Voltairos's critical diatribe was based only on that of Macpherson. This is not what Vagenas wrote nor is it what I translated.

${ }^{2}$ Like Gustave Flourens, Leroux died in the Communes in 1871.
} 
that Kephallinos was the first Greek who translated 'The Poems of Ossian' into demotic prose.

There is a startling coincidence which is similar to 'Ossian in Greece', published in April, 1967 when the Military Junta took over and changed the official language to Purist. In 1936, when a book of translated poems by Ossian was published, a military dictatorship had just come to power under General Metaxas, a pro-Royalist. He changed the official language from Purist to demotic Greek (Sarandis, 2003) at the time when this publication of Ossian was translated into Modern Greek demotic poetry. In the last eleven lines of his long footnote, Vagenas cites Stathis Spiliotopoulos's translation entitled 'Ossian Poems: Fingal, Comala, Colna-Dona, Croma, The Songs of Selma' and Berrathon, published in 1936. He quotes the critic K. Karthaios who prefaced Spilitopoulos's book observing that this poetry comes 'to enrich Greek Letters with the translation of a work, which is almost unknown in our country'. Vagenas concurs with this opinion when he states that it does not seem exaggerated if we think when it was expressed. From the first decade of the Twentieth Century Ossian started to be forgotten, he continues (Vagenas, 1967). In the preface to Spiliotopoulos's translation there is no reference to any previous Nineteenth Century translator of 'The Poems of Ossian'. This book was published three months before the public burning of books of both Greek and foreign writers, as well as periodicals and the Press, similar to that of Nazi Germany, in a massive censorship drive led by Metaxas. Among the books consigned to the fire were the works of Goethe (Petropoulos, 2001). One of its censors was Kleon Paraschos, (a nom du plume) who is given one line by Vagenas, as the reviewer of Spiliotopoulos's translation (Vagenas, 1967) ${ }^{1}$.

Vagenas states that in his work, Spiliotopoulos gave his most complete Greek translation of Ossian including Fingal, Comal, Colna-Dona, Croma, The Songs of Selma and Berrathon. This is misleading. Is Vagenas referring to complete translations of poems from 'The Poems of Ossian'? Or does he mean that up until that point no book had been published that contained more than two translations and therefore Spiliotopoulos's work was more important as it contained six poems - the most translations - in one book? Many complete translations were published in the Nineteenth Century including: Fingal, Books I-VI 1869; Dar-thula, (1862 and 1885); Lathmon (1862 and 1890); The Songs of Selma (1843, 1848, 1879, 1882); Oscar and Dermid (1878); Oina-Morul (1876 and 1880); The War of Inisthona (1880) ${ }^{2}$; Oithona (1880 and 1884); The Death of Cuchullan (1887); Minvane (1890 and 1894). Voltairos's critical diatribe contains forty pages compared to just ten by Spilitopoulos. A long extract from Temora Book I entitled 'The Death of Oscar' in 1875; another extract from Temora Book IV entitled 'The Dream of Cathmor and Sulmalla' in 1865, the fragment following 'Croma', which Spiliotopoulos omits, entitled 'Five Bards', Bard I and Bard IV in 1856, extracts from 'The Songs of Selma' in 1871 and 1873, and a long extract from Fingal Book 1, a short one from

\footnotetext{
${ }^{1}$ The name of the censor K. Paraschos is omitted in Howard Gaskill's edited version of my translation.

${ }^{2}$ By A. N. Kephallinos, which was excluded from Vagenas's paper (Kephallinos, 1880b)
} 
Book 4, Oscar and Dermid (Fragment VII) in 1863. These translations were selected for political reasons. For example, the poem 'The Songs of Selma' was used to convey the underlying political hopes that unity is better than war. The 'Star' represented hope. Once united the indigenous people of different faiths would enjoy autonomy without foreign monarchy. It was, moreover, vital that this poetry was circulated in newspapers and periodicals, rather than in book form, throughout the Greek-speaking world, as it would reach the greatest readership at particular points in time. Certain poems were used to expose Western diplomatic machinations as they imposed their monarchs on liberated Ottoman territory. At the same time, this work instilled unity through the example of magnanimity of Fingal and his followers. It can be concluded, therefore, that the vast distribution of Nineteenth Century translations of 'The Poems of Ossian' by James Macpherson had already entered Modern Greek literature enriching the Greek language and culture well before Spiliotopoulos's six poems were published in one tome in Athens in 1936. It had not been forgotten: merely neglected.

Metaxas also banned the performance of the play 'Rigas; written by Vasillis Rotas, which was to have been performed on the national day $-25^{\text {th }}$ March - in 1937 (Tsokopoulos, 1998).

As the Ossianic epic poem 'Rigas the Inspirer', written by Julius Typaldos, the Kephalonian scholar and judge, occurs at the same time as Typaldos's translation of 'The Poems of Ossian' Vagenas dates these translations as being at or before 1856. Published in Zakinthos, part of the British Protectorate, in 1856 , 'Rigas the Inspirer' was the first poem in a book of poetry by Typaldos (Vagenas, 1967).

This epic poem entitled 'Rigas', dedicated to Solomos, extols the virtues of this pro-martyr Balkan hero of the Greek Revolution who was a scholar, a bard and political visionary.

'Under a tree the young singer sits as the stars,

Mountains, seas and forests look on; and his spirits in the

Heavens gradually took flight. The cool evening breeze kissed

His face, as if it wanted to snatch the song from his lips, so as

To mysteriously blend it with hidden harmony where at night

The leaves of the citrus tree rise.

And:

All at once the young man awoke and facing the lands and

The people of the East a clear light opened again, where

Ascending on high, gradually it was extinguished'

(Konomos, 1953).

Rigas envisioned a Balkan-Anatolian confederation of republics, without foreign monarchy, whose laws would be built on Ancient Greek democracy and the French Revolution instilling equality, justice, fraternity and toleration of all faiths (Cordahi, 2002). In order to uplift the morals of the oppressed, in 1790, Rigas published one of the first Modern Greek novels, in the vernacular, 
entitled 'School of Delicate Lovers', which is based on the works of Restif de la Bretonne (Velestinlis, 1994) ${ }^{1}$. Restif de la Bretonne also wrote 'Veilles du Marais' in 1785, which contained extracts from The Poems of Ossian, including 'Oithona' (Van Tieghem, 1917). When Rigas's lost documents were found on Zakinthos in 1871, by the Zakinthian historian P. Chiotis, the publication was followed shortly by A. S. Livanthinopoulos's translation of a fragment from 'The Songs of Selma' (Livathinopoulos, 1871). This was followed by quite a few other translations from 'The Poems of Ossian' including the performance of the opera 'Oithona' in 1876 and in 1880, composed by the Corfiot D. Rodotheatos. These translations conveyed a political message, the most important of which was to preserve unity, especially those translated by Panayiotis Panas, the main translator of 'The Poems of Ossian', who founded the Democratic Eastern Federation in 1868. The DEA later came under the umbrella of the 'Rigas Association' in 1875. As Rigas Velestinlis's work has also been neglected (Legrand, 1892) it can be inferred that this explains the silent neglect of Nineteenth Century translations of 'The Poems of Ossian', which are related.

Following the poem 'Croma', is a fragment entitled 'The Six Bards'. Five bards gathered together by a chief, who was a poet himself and asked each bard to compose a song about the night. Cesarotti translated and entitled this fragment 'La Notte' (The Night). Typaldos translated two fragments from Cesarotti's 'Nights' or 'The Bards' from 'Croma'. Vagenas goes on to state that had Typaldos's poems, which remained unpublished until 1915, been published in their time, they would certainly have created a sensation. The French critic Mme J. Lamber translated two songs entitled 'Escape' and 'Two Flowers', written by Typaldos and set to music by the radical Zakinthos composer Pavlos Carrer, (1829-1896) into French, in the Nineteenth Century. Madame Lamber claims that if you were to ask a Greek if he knew who Typaldos the poet was, he would probably plead ignorance. But if you asked him if he knew the songs 'Escape' and 'Two Flowers', he would definitely know them. Extracts of these songs were published in 'Byron' in 1874, when the Kephalonian scholar A. Laskaratos wrote an article entitled 'Seven Syllables' using Typaldos's lyrics as examples (Laskaratos, 1874). So Typaldos's poetry was already renowned in the Nineteenth Century

The critic Marinos Sigouros, who was born when Italian was removed from the State syllabus in 1885, claims that the Italian poet Leopardi influenced Typaldos. The translation of The Poems of Ossian by Cesarotti was not mentioned (Sigouros, 1916). Therefore any connection between 'The Poems of Ossian' and Modern Greek writers was diverted (a translation into Greek of Leopardi's 'To the Moon', shows the influence of Ossian on his poetry. See Leopardi, 1941). At the beginning of the Twentieth Century,

\footnotetext{
${ }^{1}$ Based on Restif de la Breton's Le petit Auvergnat, Le garcon de boutique, Le nouveau Pygmalion, L'honneur eclipse par l'amour, le premier amour, La mort d'amour. Vienna: Doukas, 1790. [in Greek]. The origin of 'School' i.e. Restif de la Bretonne, was only brought to light in the $1940 \mathrm{~s}$ in Athens.
} 
Sigouros changed a line in Typaldos's poem 'To the Union of New Territory 1881'. The lines are as follows:

'Beware! Beware! The glorious day of Restoration

Behold! The West turns towards you

And with a troubled glance, I look. (My translation of Typaldos)

Sigouros's lines are:

'The West turns its glance towards you -

With secret distrust I look at you'

(Sigouros, 1916).

Sigouros also did not refer to his source, which was taken from the front page of 'Phoni' (Voice), a newspaper published in Corfu on $15^{\text {th }}$ October, 1881, when Thessaly and a minute part of Epirus were united to Greece.

In 1950, the critic Evangelos Vlachos was called to task for praising Typaldos's poetry to the hilt, believing he should be at the forefront of Modern Greek poetry. Writing in the Anglo-Hellenic Review, Alkis Thrillos stated that Typaldos belonged to the level of 'Poeta Minores' (Thrillos, 1950). Making no reference to Cesarotti, the critic Mario Vitti states that Typaldos lacks true creative inspiration (Vitti, 1989).

Although the first song of 'The Bards' by Typaldos was included in the second year upper high school curriculum in a book on Modern European literature as an elective in 1998, this poem has now been withdrawn from the curriculum. The introduction to Macpherson's Ossian shows the famous painting by Ingres entitled 'The Dream of Ossian'. The introduction mentions Melchior Cesarotti's translation that influenced the Seven Islanders. It refers to 'Dar-thula' and its opening apostrophe to the moon, which it recommends reading, together with Goethe's ballad 'Exotic' translated by Ioannis Papadiamantopoulos (Jean Moréas) and 'Ode to the Moon' by Solomos. The article stresses the use of ghosts of the dead that appeared in this romantic poetry. One of the editors of this school book was Vagenas (An Anthology, 1998). As no mention is made of any other Nineteenth Century Modern Greek translations of 'The Poems of Ossian' this does not present a true picture as to why this Celtic poetry was translated into Modern Greek in the Nineteenth Century and the consequent cultural legacy the translators bequeathed.

The following words which Typaldos uses in his translations of the fragment 'Bard I' and 'Bard IV' are attributed to later writers in the 1991 edition of Tegopoulos Phytrakis Greek Dictionary.

The First 'Bard'.

arada ( $\alpha \rho \alpha \dot{\delta} \delta \alpha)$ [line, row] (Malakassis, Kavvadias)

acharo (ó $\chi \alpha \rho)$ [inelegant] (Gryparis)

greeko $(\gamma \rho о i ́ \kappa \omega)$ [hear, listen] (Varnalis)

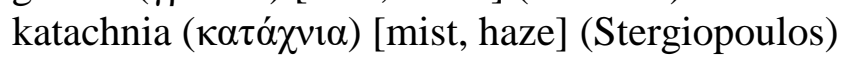

rovoloun ( $\rho \circ \beta$ o $\lambda$ ov́v) [tear, tumble, rush down] (Hadjidakis)

The Fourth 'Bard'. 


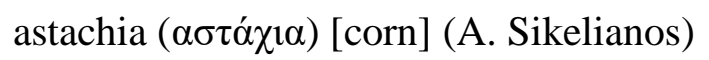

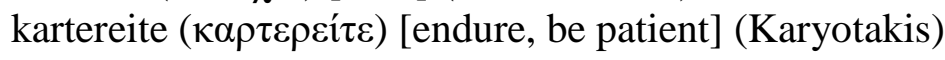

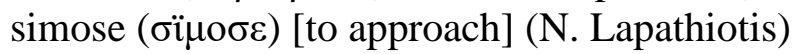

soriasmena ( $\sigma \omega \rho 01 \alpha \sigma \mu \varepsilon \dot{v} \alpha)$ [heap. pile] (Palamas)

(Tegopoulos-Phytrakis, 1991)

In Panas's 1875 extract from 'Temora' Book I entitled 'The Death of Oscar' (Panas, 1875) ${ }^{1}$-excluded from Vagenas's paper- written in Purist, there are several words that are attributed to subsequent poets including achnizon

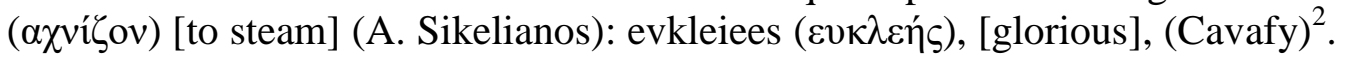
It is noteworthy that Cavafy's own library in Alexandria contains a copy of 'The Poems of Ossian' by James Macpherson (Macpherson, 1847), and 'Werther' by Goethe in French. Voltairos (1869) uses the ancient Greek word thirevo $(\theta \eta \rho \varepsilon v ́ \omega)$ [to hunt], which is attributed to K. Kariotakis. Another

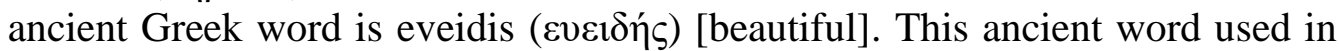
modern form is ascribed to Cavafy when in fact Voltairos recycled it in his translation of 'Fingal' before then (Tegopoulos-Phytrakis, 1991). The demotic prose translations of 'Oinamorul' and 'Oithona' by Kephallinos (1880a) include diavainoun ( $\delta 1 \alpha \beta \alpha$ ívovv) [go across, pass] attributed to both G. Geralis and Malakasis; chlorasia ( $\chi \lambda \omega \rho \alpha \sigma i \alpha)$ which is credited to K. Krystallis; paradernis $(\pi \alpha \rho \alpha \delta \varepsilon \dot{\rho} \nu \eta \varsigma)$ [beat,thrash, flounder, drift] is attributed to $\mathrm{T}$.

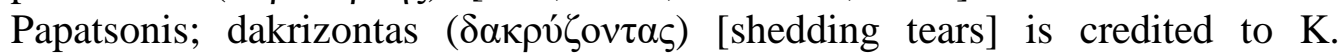
Palamas; and the recycled ancient Greek word faretra ( $\varphi \alpha \rho \varepsilon ́ \tau \rho \alpha)$ [quiver] to A. Sikelianos (Tegopoulos-Phytrakis, 1991).

From the above it can be concluded that the impact of the work by Nineteenth Century Modern Greek scholars who translated 'The Poems of Ossian' by James Macpherson has been grossly neglected by Twentieth Century critics with very little credit given to the translators. Besides enriching the language, this poetry was also used as an ethical precept in connection with a political movement. The choice of fragments and poems selected from 'The Poems of Ossian' by these Nineteenth Century Modern Greek translators published at important historical moments reveal how it was used to bring unity under democracy in the face of Western monarchical kingdoms taking over Ottoman territory in the Balkans and Anatolia. Let us hope that Twenty First Century Modern Greek literary critics will correct these omissions and inaccuracies in order to bestow the richly deserved honour on those Nineteenth Century Modern Greek scholars, who translated this Celtic masterpiece.

\section{References}

Bouboulidos, F. G., 1950. The Bibliography of George Tertsetis. Hellenic Dimiourgia, 15 January-15 June, pp.117-120. [in Greek]

\footnotetext{
${ }^{1}$ I am grateful to Professor Stavropoulou who gave me a copy of this poem in 1996.

${ }^{2}$ See Greek Dictionary.
} 
Byron, G.G., Lord., 1919. The Works of Byron. Vol II. Paris: Tauchnitz (1876) 2nd edition. Gaulon

Cordahi, A., 2002. Rhigas Velestinlis et les Transformations Juridiques. In: Rhigas Vélestinlis (1757-1798): Intellectuel et combattant de la liberté, Actes du Colloque International UNESCO, 12 et 13 décembre 1998. Paris: Unesco/Desmos, pp.226-256.

Denisis, S., 1995. Translations of Novels and Short Stories (1830-1880). Athens: Periplous. [in Greek]

Dimaras, K. T., 1987. The History of Modern Greek Literature, 8th ed. Athens: Icaros [in Greek]

Dimaras, K. T., 1994. Greek Romanticism, 2nd ed. Athens: Ermis. [in Greek]

Gaskill, H., 1994. Ossian in Europe. Canadian Review of Comparative Literature, XXI (4), pp.643-678, 652.

Gaskill, H. ed., 1996. The Poems of Ossian and Related Works: James MacPherson. With an Introduction by F. Stafford. Edinburgh: Edinburgh University Press.

Georgantopoulos, I., 1850. Ossian. "The Death of Calmar and Orla" by Byron. Evterpe, Athens pp.127-129

Goethe, J.W., 1963. Selective Connections: Werther, Hermann and Dorothea. Translated by M. Zorgraphos. Athens: Korontzi-Rapti.

Goethe, J.W., 1996. The Sorrows of Young Werther. Translated by S.G. Nikoloudi. Athens: Agra.

Gsteiger, M., 1977. Werther, René, Jacopo Ortis et la Politique: Esquisse d'une Lecture Comparative. Etudes de Lettres: Bulletin de la Faculté des Lettres de l'Université de Lausanne et de la Société des Etudes de Lettres, Serie III Tome 10. Lausanne : October-December, pp.42-53.

Guida, M., 2007. The Life and Political Ideas of Grand Vezir Said Halim Pasha [pdf]. Available at: http://www.academia.edu/235864/The_Life_and_Political_Ideas_ of Grand Vezir Said Halim Pasha [Accessed: 8 September 2012]

Kardamis, K., 2012. A Scot Bard in European South: Dionisios Rodotheato's opera 'Oitona (1876). Available through: The Ionian University website <http://ionio. academia.edu/KonstantinosKardamis> [Accessed 3.12.13].

Kephallinos, A. N., 1880a. Ossian Oina-morul. Oithona. Turin

Kephallinos, A. N., 1880b. Ossian, The War of Inis-Thona. Corfu Anthology, 1 March 1916, No.4, pp.98-102.

Konomos, D., 1953. The Complete Works of Julius Typaldos. Athens: Pigis. [in Greek]

Laskaratos, A., 1874. Seven Syllables. In: Byron, Volume A, Year A. April. p.516. [in Greek]

Legrand, E., 1892. Documents inédits concernant Rhigas Velestinlis et ses compagnons de martyre tirés des archives de Vienne en Autriche. Paris : Ernest Leroux, pp.I-VII.

Leopardi, G., 1941. To the Moon. Translated by N.B.T. New Estia, Vol. 2, pp.1-45.

Livathinopoulos, A. S., 1871. Fragment from the Songs of Selma by the Englishman Ossian. Eurydice, 35, June 30th, pp.126-127.

Mackridge, P., 1992. The Modern Greek Language. Oxford: Oxford University Press.

Macpherson, J. (transl.), 1847 (1881). Ossian. The Poems. In: Collection of British Authors. Vol. 116. Leipzig, Bernhard Tauchnitz. Available through: The Cavafy Library website<http://www.cavafy.com/archive/library/list.asp?cat=7\#7>

O'Donnell, K.A., 2014. Nineteenth-Century Cycladic Warriors: Celtic Heroes. In: S.M. Oberhelman., ed. Studies on Mediterranean Culture and History: From the 
Middle Ages through the Early Modern Period. Athens: Athens Institute for Education and Research.

Panas, P., 1862. Dar-thula-Lathmon Poems of Ossian. Kephalonia, British Protectorate: Kephallinia

Panas, P., 1865. Temora IV, the Death of Calmar and Sulmalla. In: Memnon the collection of various poems. Alexandria: Nile. [in Greek]

Panas, P., 1875. The Death of Oscar, extract from Temora I. Exergersis, 22 March, pp. 4-5.

Petropoulos, G., 2001. Books on the Fire. Sunday Rizospastis, 23 September, p.13. Athens. [in Greek]

Ravanis, G.D., 1982. Byron in Cefalonia. Translated by H. Cosmetato. Athens: Corgialenios Foundation, Historical and Cultural Museum of Cefalonia

Sarandis, C., 2003. The Ideology and Character of Metaxas. [pdf] Available at: <http://www.arts.yorku.ca/hist/tgallant/documents/sarandismetaxas_001.pdf> [Accessed 17.6.14].

Sigouros, M., 1916. Julius Typaldos, Poems. Athens: Fexi. [in Greek]

Stafford, F., 1991. Dangerous Success: Ossian, Wordsworth and English Romantic Literature. In: H. Gaskill, ed. Ossian Revisited. Edinburgh: Edinburgh University Press. pp.49-72.

Stavrianos, L. S., 2000. The Balkans since 1453. London: Hurst \& Co.

Stavropoulou, E.-L., 1987. Panayiotis Panas: A Romantic Radical. Athens: Epikairotita. [in Greek]

Tegopoulos-Phytrakis, eds., 1991. Greek Dictionary: of Spelling, Interpretation, Etymology, Synonyms, Antonyms and Proper Nouns, 5th edition. Athens: Harmony.

Thrillos, A., 1950. Julius Typaldos. Anglo-Greek Review. Athens: September-October, pp.253-254.[in Greek]

Tsokopoulos, V., 1998. Rhigas Vélestinlis (1757-1798). Rhigas dans l'état hellénique: commemorations, interpretations et silences In: Actes du Colloque International UNESCO. 11-13 Décembre 1998. Rhigas Vélestinlis (1757-1798): Intellectuel et combatant de la liberté. Paris : Desmos.

Typaldos, J., 1998. Ossian Night. In: An Anthology of Translations for Second Year Upper High School, Modern European Literature. Contributors: N. Vagenas, T. Kagialis, L. Polkas, N. Taras, G. Fragkoglou. Athens: Didaktikon, National Ministry of Education and Religion [in Greek], pp. A8/61 - A/9/66.

Vagenas, N., 1967. Ossian in Greece. Parnassos, 9. Athens: [in Greek]

Van Tieghem, P., 1917. Ossian en France, Tome I, Paris: F. Rieder \& Cie.

Velestinlis, Rh., 1994. School for Delicate Lovers. In: P.S. Pistas, ed. Apanda. Athens: Kollarou.

Vitti, M., 1989. Histoire de la Littérature Grecque Moderne. Paris: Hatier.

Voltairos, G., 1869. Ossian, Fingal an epic poem. Athens: Moraitini. 